\title{
Solar Based MPPT To Drive BLDC Motor
}

\author{
Krushna Namdeo Gunjal ${ }^{1}$, Milind Ashok Ukey², Ajhar Mohammad Sheikh ${ }^{3}$, Sneha Bharat \\ Sahare $^{4}$, Shital Prakash Thombare ${ }^{5}$, Dr. Jagdish G. Choudhary ${ }^{6}$ \\ ${ }^{1-5}$ Students, Department of Electrical Engineering, \\ Nagpur Institute of Technology, Nagpur, India, 441501 \\ ${ }^{6}$ Head of Department, Assistant Professor, Department of Electrical Engineering, \\ Nagpur Institute of Technology, Nagpur, India, 441501
}

Received on: 03May, 2021

Revised on: 30 May, 2021

Published on: 01 June, 2021

\begin{abstract}
The main aim of this project deals with developing a PV module connected brushless dc motor using maximum power point tracking algorithm. $P$ and $O$ algorithm is one of the simplest and effective methods of MPPT. In this method, maximum power is extracted from the solar model.

The system model and interleaved boost converter are providing the reduce ripple content, switching loss and also promote the efficiency of the system. The speed controls of the BLDC motor are tested under the load condition. The model is designed in MATLAB simulation to ensure its working condition and also check the behavior of Interleaved boost converter. This project presents photovoltaic system with a maximum power point tracking (MPPT) controller is connected to brushless motor.
\end{abstract}

\section{I- INTRODUCTION}

$\mathbf{P}$ $\mathrm{V}$ energy plays an important role in the whole world and they have various range of application like solar power used in the space program for satellite. Also rapid increment in demand of electricity and change in the environment condition due to a high amount of use fossil fuel energy such as global warming so need cheaper and substance having fewer carbon emissions so the huge effort has been given by the researcher to grow up the new technology for energy resource to its increased in a few years. In the PV system direct conversion of solar energy into electrical energy, no of a solar cell are connected together to form a solar array or solar module but the drawback of PV system is installation cost is high also efficiency is low of PV system so this drawback is overcome by maximum power point tracking. In this system, the interleaved boost converter is used. IBC has various advantages like low ripple content, efficiency it should high also switching loss will be low. high power application IBC is used. In this work, the solar PV system is used to drive BLDC motor because the relevance of BLDC motor has been increased day by day in industrial sector of the whole world. Solar is one of the alternative energy sources since the overall cost of required for implementing is higher. They are mostly employed for high power applications.

\section{II- LITERATURE SURVEY}

1) Modelling of a photovoltaic system with different mppt techique using matlab/Simulink IEEE 2018 Paul Christodoulides et.al

2) Perturb and observe based mppt for solar power generation connected to ac load 2017 IEEE Deepak S. Suryawanshi

3) Introduction of a photovoltaic system maximum powerpoint tracking.

\section{III- PROPOSED SYSTEM}

Renewable energy sources have become an indispensable part of world energy consumption during the recent years as these energy resources not only contribute significantly to meet global energy needs, but also provide a surplus for the same. Currently, solar energy is gaining popularity as it is the most viable source of energy profusely available. Ample research has been done on SPV technology to exploit it for 


\section{International Journal of Innovations in Engineering and Science, www.ijies.net}

industrial applications. Further, the advancement in technology has led to reduction in the price of SPV components, making it available for use in several applications. In earlier system BLDC motor load is not connected directly to solar panel, this is achieve by MPPT. This study aims to show that employing an effective MPPT controller and replacing a conventional motor like the brushed DC or induction motor with a BLDC motor can accomplish a considerable energy saving in a standalone PV power system.

\section{IV- METHOLOGY}

In this technique, the value of generated power from the solar PV module is calculated and compared with the previous value of power which is stored in a memory of an algorithm, which gives the difference in the value of the power.

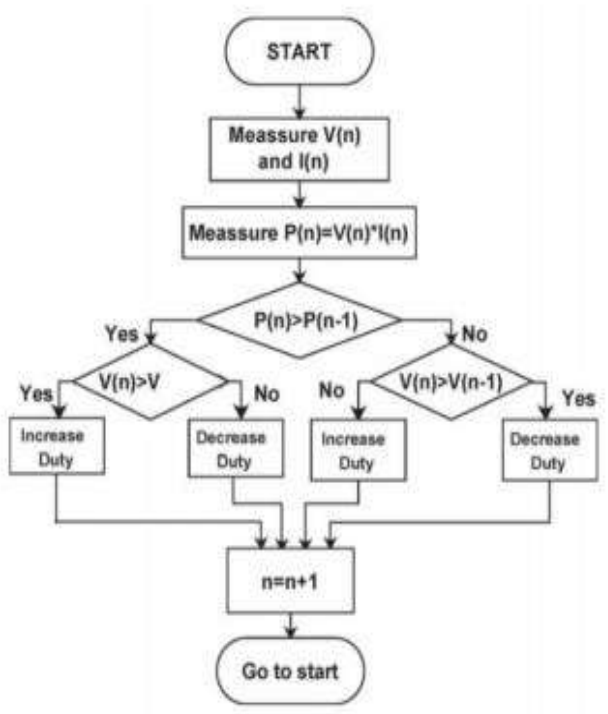

Fig. 1. $P$ and $O$ Algorithm

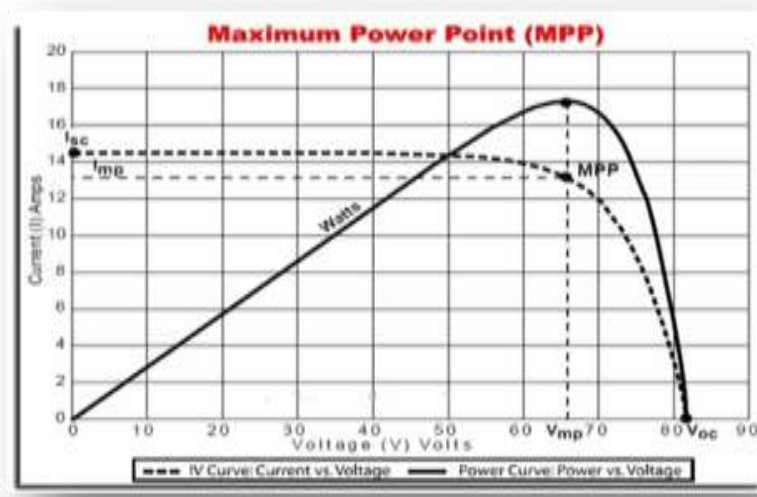

Once the tracking direction is incorrect, the technique becomes confused and its go away from the MPP. The third one is that $\mathrm{P}$ and $\mathrm{O}$ method will not capable of track maximum power under partial shading condition. Suppose the current power of solar module is on the left side of MPP then changes in a duty cycle of DCDC converter so then cause of this perturbation is a change in the voltage and current of module. In $p$ and o technique current power and previous power difference are positive as MPP is on the left side and the duty cycle of the converter is change till these differences have become zero.

\section{V- SOLAR PHOTOVOLATAIC SYSTEM}

A solar cell is that convert the light energy into electrical energy on photovoltaic effect. It is a P-N junction semiconductor junction Figure 1. shows the circuit diagram of the solar cell. In which is diode is parallel in connected with source current for to developed solar PV cell. The solar panel is used to generate DC power from solar energy. In which there is a $\mathrm{P}-\mathrm{N}$ junction

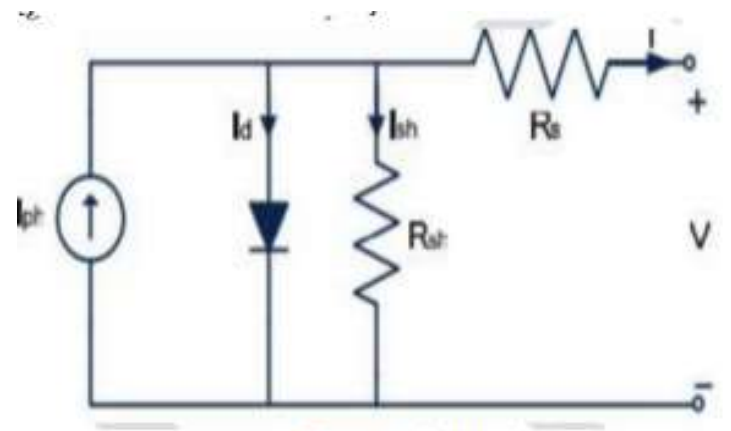

Fig. 2. Solar Cell

\section{VI- INTERLEAVED BOOST CONVERTER}

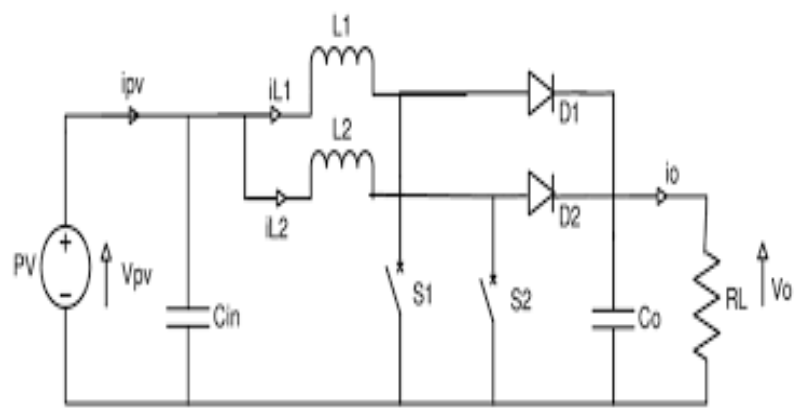

Fig. Interleaved Boost converter

DC-DC converter is play a huge role in the form of various topology in various Electrical application. Interleaved means connect two or more circuit in parallels, so IBC is there is two or more boost converter connected in parallel and operated by $2 \pi / n$ radians or same phase shift among switches and duty cycle should 


\section{International Journal of Innovations in Engineering and Science, www.ijies.net}

be same This type of Dc-Dc converter have many advantages such as switching loss low, minimum current, and voltage ripples and efficacy of IBC it should be high as compared with other conventional boost converters. In IBC the total no of power is divided into no. of converter connected in parallel.

\section{VII-BRUSHLESS DC MOTOR}

This motor widely used in many sectors because of brushless motor have a good dynamic response, size of motor less over other motor. Main thing is efficiency of the motor so this parameter is mostly considered at the time of motor selection, in that case BLDC motor have high efficiency. Also, maintenance cost is low as compared with other motor. In the developed system BLDC motor is used as load. In which we DC supply is provided Via an inverter which is used produced Ac current to drive each phase of BLDC motor with the help of BLDC motor Controller. Hall sensor is used to measure the actual position of rotor. It should be most important parameter in speed control of motor in closed loop speed control but due to hall sensor the cost of system is increased.

\section{DESIGN}

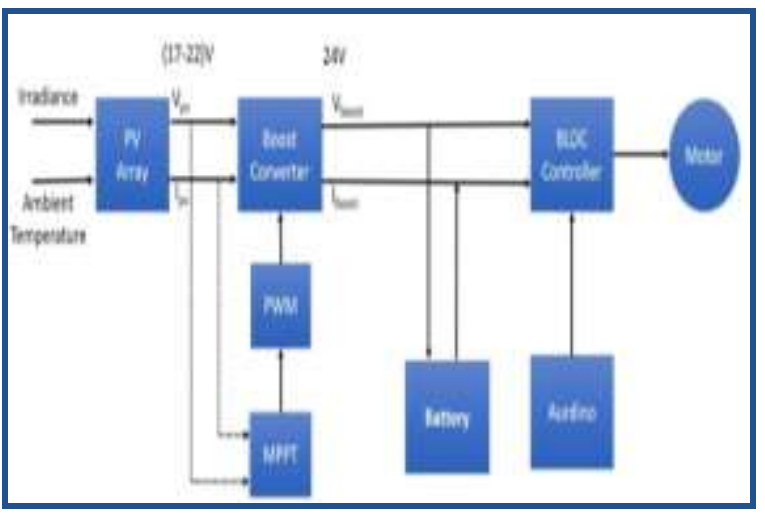

The figure shows the Implementation block diagram of the system in which consist PV array, dc to dc converter. For maximum power is exact from the array one algorithm is implemented in this system the name of the algorithm is $\mathrm{P}$ and $\mathrm{O}$ algorithm in which power comes from PV module save in the memory of system so in another step newly power comes from solar module is compared with previous power value which is already stored in the memory. If the previous value is higher than the current power value so the duty cycle of IBC is changing to get the maximum power. Then the output of IBC is given to the Inverter to get constant output power and consequently constant output torque to drive the BLDC motor by switching the stator winding of motor in sequence. The motor controller is used to sense the position of rotor and speed of the motor from a hall effect sensor and generate the switching signal for the three-phase inverter to an electronic commutation of motor. In the closed-loop speed control technique, the actual speed is measured and it should be compared with reference speed to find speed error and this difference is provided to PI controller to reduce the speed by changing the switching signal of the inverter.

\section{VIII- SIMULATION MODEL}

In the above figure, we can see that the complete simulation diagram of solar power fed brushless dc motor. The maximum power is transfer from solar system to BLDC Motor with the help of MPPT Algorithm. In the simulation model, the BLDC motor used to drive the specific load Application.

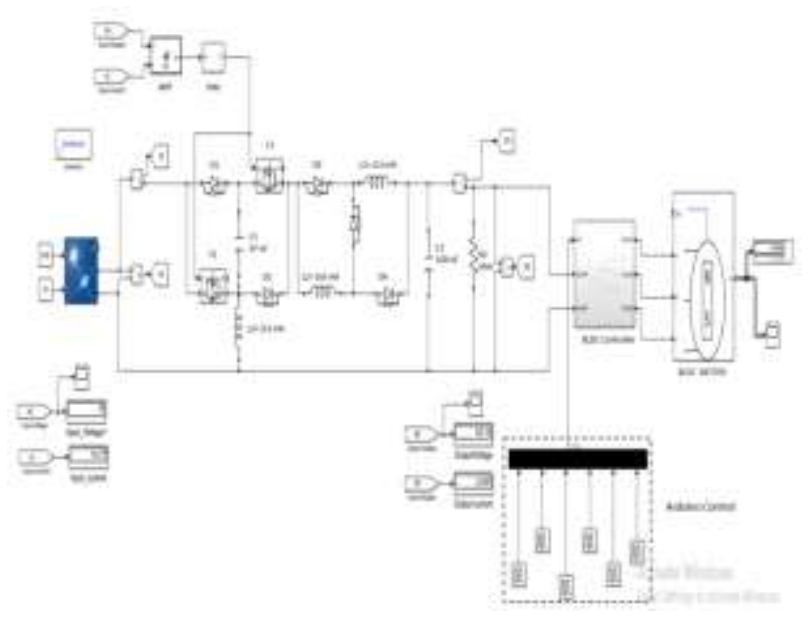

Fig. MATLAB Simulation of Developed system

\section{IX-CONCLUSION}

In conclusion, BLDC motors have advantages over brushed DC motors and induction motors. They have better speed versus torque characteristics, high dynamic response, high efficiency, long operating life, noiseless operation, higher speed ranges, rugged construction and so on. We can extract maximum power from a solar array with the help of $\mathrm{P}$ and $\mathrm{O}$ algorithm. Interleaved boost converter is used in the system so that we can found that the IBC was helped reduced content from the output as well as input side also it can reduced stress on switches. IBC suitable for converter high power energy source. A feedback signal from motor indicates the speed and position of the motor which is utilized to generate the switching signal for the inverter 
Vol. 6, No. 5, 2021, PP. 18 -21

\section{International Journal of Innovations in Engineering and Science, www.ijies.net}

\section{REFERENCES}

[1] Abhilash Nilkanth Jadhav1 Dr. V. A. Kulkarni2 1,2 "MPPT Techniques for PV Connected BLDC Motor Drives" (IJSRD/Vol. 7/Issue 03/2019/355).

[2] Deepak.S. Suryawanshi, Sunita S. Khairnar "Perturb and Observe Based Mpptfor Solar Power Generation Connected To Ac Load" 2017 2nd IEEE International Conference On Recent Trends in Electronics Information \& Communication Technology (RTEICT), May 19-20, 2017, India.

[3] M.Poovizhi M.Senthil Kumaran P.Ragul L.Irene Priyadarshini "Investigation of mathematical modelling of brushless dc motor(BLDC) drives by using matlabsimulink"IEEE 2017

[4] Ashwin Chandwani, Abhay Kothari Department of Electrical Engineering Institute of Technology, Nirma University Ahmedabad, India and Department of Electrical Engineering Institute of Technology, Nirma University Ahmedabad. India" Design, Simulation and Implementation of Maximum Power Point Tracking (MPPT) for Solar based Renewable Systems" 2016 International Conference on Electrical Power and Energy Systems (ICEPES).
[5] T. Nivethitha1, R.Anand 2 "PV Connected BLDC Motor Drive by Employing P\&O MPPT Controller" JIRSETVol. Special Issue 6, May 2015

[6] RadakBlangeChitralekha Mahanta Anup Kumar Gogoi "MPPT of Solar Photovoltaic Cell Using Perturb \& Observe and fuzzy Logic controller Algorithm for BuckBoost DC-DC Converter" Dept. of Electronics \& Electrical Engineering Indian Institute of Technology Guwahati, Assam, India. 2015 IEEE

[7] EI SHWE ZIN PHYO1, KYAW SOE LWIN2, HLA MYO TUN3 "Solar Smart Charge Controller using MPPT" ISSN 2319-8885 Vol.03, Issue.06, May-2014, Pages:0997-1000

[8] A. Thenkani, Dr. N. SenthilKumar Design of Optimum Maximum Power Point Tracking Algorithm for Solar Panel" International Conference on Computer, Communication and Electrical Technology - ICCCET 2011, 18th \& 19th March, 2011

[9] D. Faiman, "Assessing the Outdoor Operating Temperature of Photovoltaic Modules", Progress in Photovoltaic: Research and Applications, Volume 16 Issue 4, Pages 307 - 315, Published Online: 21 Feb 2008, Copyright (c) 2009 John Wiley \& Sons, Ltd. 